\title{
El imaginario de la Segunda República española en el cine de ficción (1940-2011)
}

\author{
IGOR BARRENETXEA MARAÑÓN \\ Universidad del País Vasco
}

\begin{abstract}
Resumen
En las últimas décadas, diversos historiadores han abierto nuevas vías de investigación, tratando de estudiar la importancia del cine como fuente histórica y como nueva forma de escribir la Historia; además de profundizar en su influencia en la conformación de mentalidades, de la memoria histórica y del imaginario colectivo. Pero todavía, en España, hay amplios territorios abiertos sin explorar como es el estudio de la visión que el cine de fícción ha transmitido del período histórico de la Segunda República española hasta 1936 (a diferencia del posterior de la Guerra Civil). Por ello, el objetivo de este artículo es desvelar las claves cinematográficas del modo en el que el cine ha retratado el periodo de la Segunda República, en relación al contexto histórico pasado y presente (momento de su rodaje), desde 1940 a 2011.
\end{abstract}

Palabras clave: Cine, Historia de España, Segunda República, memoria histórica, imaginario.

The Imaginary of the Second Spanish Republic in Fiction Cinema (1940-2011)

\begin{abstract}
In the last decades several historians have opened new investigation channels trying to study the importance of the cinema as a historical source and as new means of writing History, as well as deepen in its influence on shaping mind-sets, historical memory and collective imaginary. However, in Spain there are yet wide-open unexplored territories such as the study of the point of view fiction cinema has delivered of the historical period from the Second Spanish Republic to 1936 (as opposed to that following the Civil War). That's why the goal of this article is to unlock the cinematographic keys on how the cinema has portrayed the period of the Second Republic in relationship to the past and present (time of filming) historical context, from 1940 to 2011.
\end{abstract}

Keywords: Cinema. History of Spain. Second Republic. Historical memory. Imaginary. 


\section{Introducción: memoria e historia}

No hay duda de que las memorias traumáticas de ciertos acontecimientos históricos son una cuestión que a las sociedades humanas les es difícil encajar en su imaginario $^{1}$. El tiempo aporta nuevas visiones y revisiones, igual que ha sucedido en Alemania o Japón, sobre el nazismo o el militarismo nipón, y España vive su propia reactualización a través de un encendido e intenso debate no solo académico sino político, social e institucional. Esto es algo que se nos aparta de nuestro trabajo aunque, obviamente, no se puede ignorarlo porque viene vinculado al modo en el que se impulsan o determinan las políticas de la memoria.

No obstante, buscaré en este territorio común del gobierno republicano, en la etapa de 1931-1936, las referencias que me interesa resaltar.

¿Qué fue del recuerdo de la Segunda República? ¿Cuál ha sido el legado que parece haber quedado en los registros de la imagen? ¿De qué modo la ficción nos ayuda a acercarnos al pasado o de qué modo aquella condiciona la visión que tenemos de la Historia? Las respuestas nunca son del todo sencillas, pero intentaré, en la medida de lo posible, irlas dando una a una. Este artículo utiliza como fuente fundamental la imagen a la hora de perfilar el modo en el que la Segunda República española se ha adentrado en el imaginario colectivo de los españoles a lo largo del tiempo. Una perspectiva que, sin embargo, siempre hemos de pensar abierta a la interpretación, nunca cerrada del todo, ni completa (ante la ingente cantidad de películas) pero sí exhaustiva, aunque intentaré abordar una buena cantidad de filmes de ficción (dejando a un lado los documentales) que, a mi juicio, son suficientemente representativos. Tras el impulso dado a la historiografía y filmografía por la recuperación de la memoria de la represión, considero que hemos de fijarnos en aquellos aspectos que han sido menos tenidos en cuenta: la memoria republicana sobre la que, muchas veces, hemos pasado de largo rápidamente, para encontrarnos directamente con la Guerra Civil española.

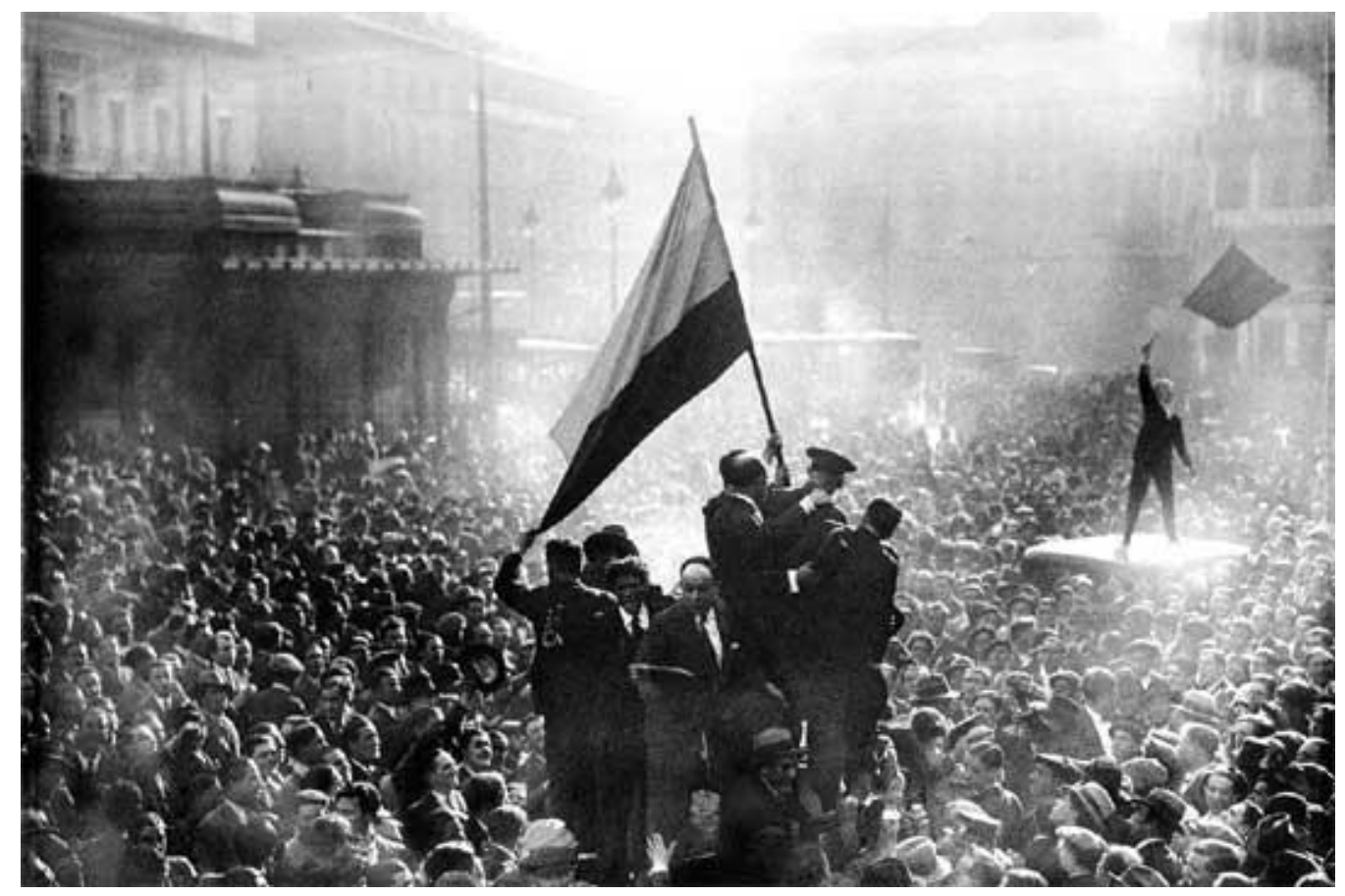

\footnotetext{
${ }^{1}$ Solo hay que apreciarlo con la reacción de la emisión de la $1^{\circ}$ Temporada de la seria sobre la República, 14 de abril. La República. Para un análisis más detallado véase: BARRENETXEA, Igor, "14 de abril. La República, análisis de la visión de la Segunda República española desde una serie televisiva”, XII Congreso de Historia Contemporánea. Pensar con la Historia desde el siglo XXI, “, del 17 al 19 de septiembre de 2014, Madrid
} 
Es obvio considerar que las memorias no se integran en el discurso histórico de la misma manera que este las incorpora en su bagaje intelectual, viven tiempos diferentes porque se configuran de una manera distinta ${ }^{2}$. Este estudio es un acercamiento únicamente al modo en el que la República ha sido dibujada en lo que estimo son tres periodos diferentes de tiempo, sin adentrarme a debatir sobre la conveniencia o no de los registros de la memoria o el papel que ha podido jugar ese ansia de memoria en privilegiar unos aspectos de la misma y olvidarse también de otros, sin que, previamente, se haya instaurado un consenso adecuado.

\section{La destrucción de la República: El periodo franquista (1939-1975)}

"La noción misma de acontecimiento traumático, que, tal como es utilizada por los historiadores, es la que califica la guerra civil" ${ }^{3}$. Este trauma social de profunda raíz destructiva supuso no sólo la instauración de un Estado corporativo en España, con la implantación de la dictadura franquista, sino un intento de relectura del pasado, refundación del espíritu nacional y el borrado y vaciado que había supuesto el liberalismo en España, identificado, por supuesto, con la instauración de la Segunda República española. Eso supuso que el 18 de julio de 1936 se produjera una rebelión armada contra el primer gobierno democrático en España y, además, el desarrollo de un discurso legitimador del Nuevo régimen instaurado, justificado a través de una serie de mitos y contradicciones internas. El periodo republicano quedó, por tanto, no solo marginado sino oscurecido por los vencedores de la contienda, culpándolo de todos los males sociales productos del liberalismo y de las causas de que se hubiese provocado la confrontación armada, denominada glorioso alzamiento, frente a la opresión roja. Los españoles de ayer que habían militado en formaciones de izquierdas o defendido la República del fallido golpe de Estado provocado por los militares, que derivó en la confrontación bélica, fueron tratados de una manera ominosa, en el mejor de los casos, encerrados en campos de concentración o bien enviados a cumplir penas de prisión o de trabajo o, en el peor, asesinados ${ }^{4}$.

Este sintético cuadro de acontecimientos derivó en una construcción cultural e ideológica vinculada a esta representación de la victoria. El cine, en concreto, cobró una dimensión muy limitada, aplicando una férrea censura que se iría abriendo con el paso de los años pero que mantendría siempre activo el discurso de la legitimación de la victoria franquista en la guerra ${ }^{5}$. Y, ¿qué fue de la memoria republicana? Tal y como señala Giuliana Di Febo, fue literalmente "cancelada" modo, al franquismo le interesaba sacar a relucir los males evocadores de aquel periodo con el fin de reforzar una imagen propia y, así mismo, seguir aprovechándose de los miedos del pasado traumático para consolidar su propia construcción memorialista. Las virtudes de la epopeya nacional, la cruel guerra y los sacrificios que habían tenido que realizar en su nombre no se iban a quedar en saco roto porque la conmoción era una

\footnotetext{
2 RICHARDS, Michael, Historias para después de una guerra, Pasado \& Presente, Barcelona, 2013; GARCÍA CÁRCEL, Ricardo, La herencia del pasado. Las memorias históricas de España, Círculo de lectores, Barcelona, 2012; BERNECKER, Walter L. y BRINKAMANN, Sören, Memorias divididas, Abada Editorial, Madrid, 2009 y CUESTA, Josefina, La odisea de la memoria, Alianza, Madrid, 2008

${ }^{3}$ AROSTEGUI, Julio, “Traumas colectivos y memorias generacionales: el caso de la guerra civil", en ARÓSTEGUI, Julio y GODICHEAU, Francois (eds.), Guerra Civil. Mito y Memoria, Madrid, Marcial Pons, 2006, p. 31.

${ }^{4}$ GONZÁlEZ CALLEJA, Eduardo, COBO ROMERO, Francisco, MARTíNEZ RUS, Ana y SÁNCHEZ PÉREZ, Francisco, La Segunda República española, Pasado \& Presente, Barcelona, 2015.

${ }^{5}$ CAPARRÓS, José María, El cine español bajo el régimen de Franco, Barcelona, Universidad de Barcelona, 1983.

${ }^{6}$ DI FEBO, Giuliana, "La cancelación de la República durante el franquismo", en EGIDO LEÓN, Ángeles (ed.), Memoria de la Segunda República. Mito y Realidad, Madrid, Biblioteca Nueva, 2006, p. 117.
} 
manera de reactivar la conciencia contra aquellos presuntos riesgos en caso de que la sociedad olvidase la peligrosa naturaleza del liberalismo (democrático) ${ }^{7}$.

Dos de las primeras películas que podemos destacar en relación con lo antes expuesto son Gracia y Justicia (1940), de Julián Torremocha y Fortunato (1941), de Fernando Delgado, Rojo y negro (1942), de Carlos Arévalo y Raza (1942), de José Luis Sáez de Heredia que nos sirven para describir este periodo.

Comencemos por la primera película. Gracia y Justicia se ambienta en el periodo anterior al inicio de la contienda, en Sevilla, en los años 20. Es la historia de un matrimonio formado por Trinidad, una mujer de raza gitana apodada Morena Clara, y su esposo, el fiscal Enrique Baena. En la trama se conjugan aspectos tanto pasionales como políticos. El filme, de escasa calidad técnica, se presenta como un tiempo de corrupción y de manejos interesados de políticos corrompidos por ávidos empresarios que muestran pocos escrúpulos (crítica alegórica de los males que sacuden a la sociedad liberal y, por extensión, a la era republicana). Gracia y Justicia, alusivo al ministerio al que aspira el fiscal Baena, destila, además, ese idealista folclore andalucista ajeno a la realidad y un marcado acento católico que casa bien con los marcos prescriptivos en los que debía moverse este cine para sortear los rígidos marcos de la censura.

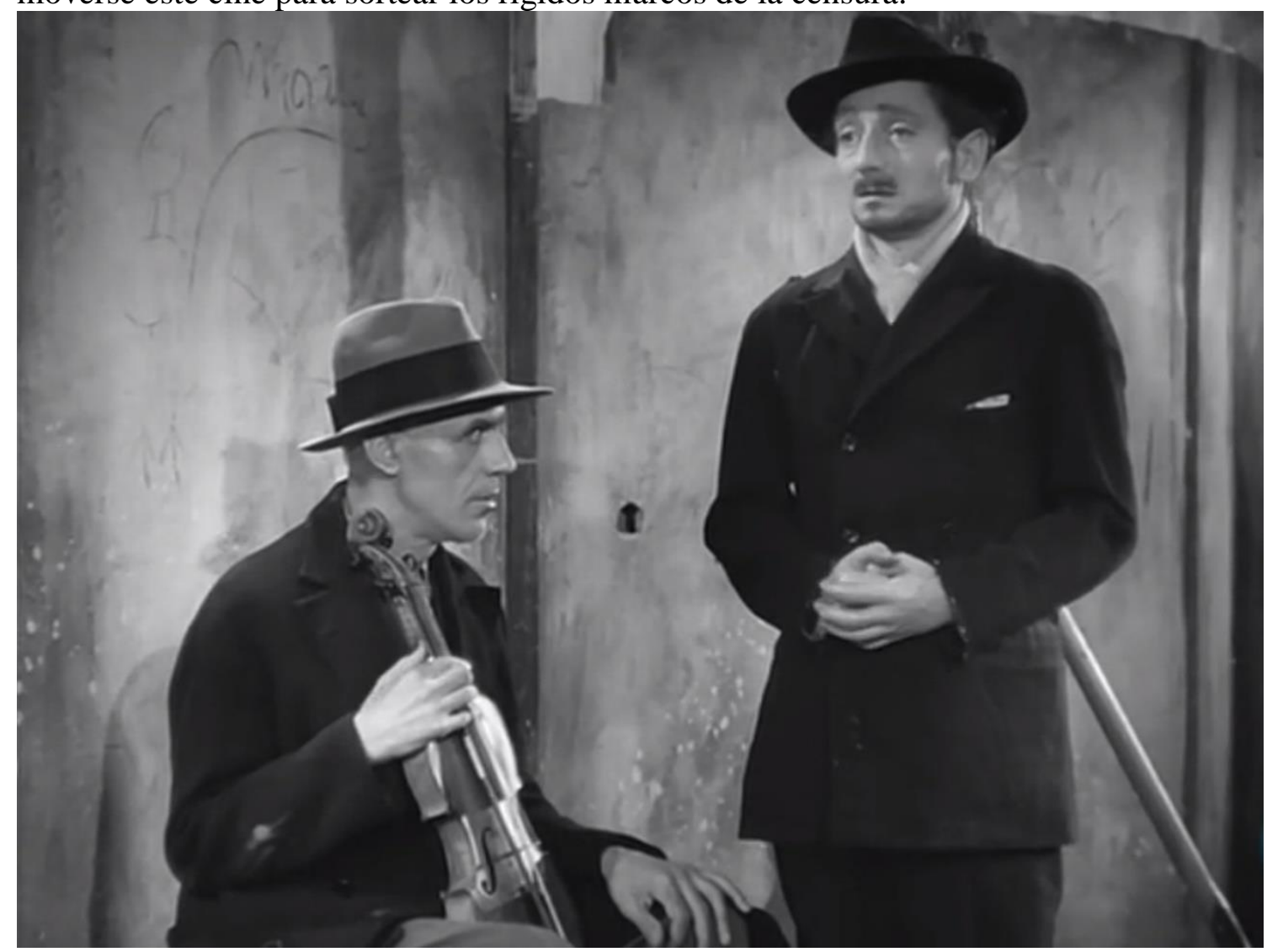

El caso del filme Fortunato es diferente. Basado en una obra de los hermanos Álvarez Quintero, ambientada a inicios de siglo, la película se contextualiza en el año 1934. La trama gira en torno a las vicisitudes de un pobre administrativo, Fortunato, padre de familia, que es despedido de su cargo debido a un tráfico de influencias, y ha de sobrellevar una serie de padecimientos hasta lograr nuevamente otro trabajo para salvar a su familia de la miseria. La historia combina el tono de drama y de comedia, al servicio del actor cómico Antonio Vico.

${ }^{7}$ RICHARDS, Michael, pp.83-108. 
Fortunato no tuvo mayores problemas a la hora de pasar la censura a tenor de que su director, Fernando Delgado, había sido uno de los documentalistas del régimen durante la guerra y miembro de la Falange ${ }^{8}$. Sin embargo, los censores sí se hicieron una observación relevante: se dispuso que el filme fuese ambientado en los años 30, de una manera más concreta debía "situar la acción antes [del] Glorioso Alzamiento"9. Decisión motivada por el temor de que en otros países se entendiera como un retrato de la sociedad del momento.

En estos filmes, sin aludir directamente al periodo republicano (eso tardaría en llegar) se pretendía "deslegitimar el ordenamiento, cultura y las instituciones republicanas" ${ }^{\prime \prime}$, aunque parecieran hablar más de la época franquista, de ahí que la censura insistiera sobre esta puntualización (ya que la obra, a fin de cuentas, ya estaba ambientada antes). Sin embargo, la película caracterizaba la pobreza material y social que vivía la sociedad de la posguerra, por mucho que el régimen quisiera ocultarla o reprobar a una etapa anterior por los males que habían abocado al golpe militar. La Guerra Civil, a la postre, había acabado por destruir no solo los pilares liberales y democráticos del periodo anterior sino consumido las fuerzas del país en una guerra sumamente destructiva en la que se habían aplicado las políticas de la venganza de una forma atroz, brutal y despiadada. En la revista Primer Plano, Antonio Mas-Guindal la valora como una "cinta española estimable y decorosa en su conjunto, lo que no es poco para nuestra producción"11. Lo que denota que el crítico no estaba muy de acuerdo con la calidad del cine español, al contrario. Hay un deje de pesimismo como si revelase el empobrecimiento cultural al que se había visto abocada la producción cinematográfica española de la posguerra.

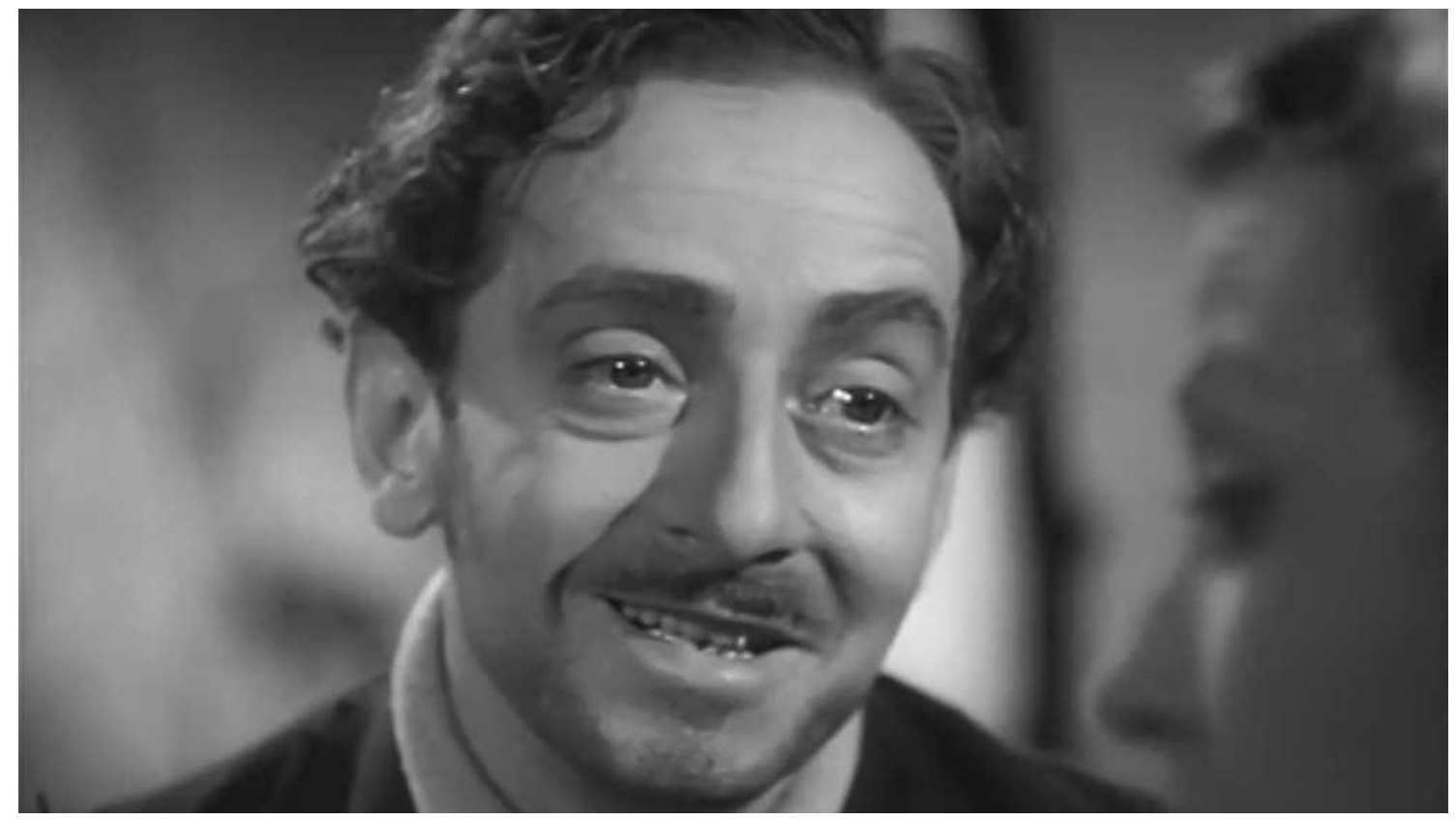

Frente a estas películas más costumbristas, nos encontramos con dos exponentes claros del cine pretendido por el régimen como son Rojo y negro (1942) y Raza (1942). Los dos constituyeron, a su modo, dos modelos de representación. Arévalo, en Rojo y negro, buscó conformar un cine falangista. Ya que su padre y su hermano, ambos

\footnotetext{
8 FERNÁNDEZ COLORADO, Luis, "Fortunato", en PÉREZ PERUCHA, Julio (ed.), Antología crítica del cine español (1906-1995), Madrid, Cátedra, 1997, p. 136.

${ }^{9}$ Archivo General de la Administración, Cultura, Caja 21/4456.

${ }^{10}$ JULIÁ, Santos y DI FEBO, Giuliana, El franquismo, Barcelona, Paidós, 2005, p. 22.

${ }^{11}$ MAS-GUINDAL, Antonio, "Fortunato", Primer Plano, núm. 69, 8 de febrero de 1942.
} 
falangistas murieron en la contienda represaliados. Por supuesto, los momentos que dedica a la etapa republicana son, sumamente, despreciativos con la democracia parlamentaria y sus valores (desde la imagen de los parlamentarios con los ojos vendados a sus actitudes). Y aunque ese protagonismo de la Falange no gustó demasiado en el seno del régimen y fue orillado, establecía muy bien cuál era la visión que se tenía del quinquenio republicano, confusión, violencia (republicana) y destrucción de la patria debido al terror revolucionario ${ }^{12}$.

A diferencia de la historia de Arévalo, Raza va a perfilar todos los (rancios) valores del franquismo, encarnados, nunca mejor dicho, en la visión que tenía Franco (guionista del filme, bajo seudónimo, Jaime de Andrade) del pasado. Película muy ampliamente tratada enfatiza, una vez más, los rasgos negativos el periodo que queda supeditado, como preámbulo inevitable y trágico, a la mayor gloria de los alzados, los guardianes de la patria en peligro ${ }^{13}$.

Otros ejemplos parecidos, aunque no tan logrados ni significativos, son los filmes Un enredo de familia (1943), de Ignacio F. Iquino y Cuando llegue la noche (1946) de Jerónimo Mihura. El filme de Iquino está inspirado en la clásica obra teatral Romeo y Julieta, aunque con notables diferencias. La historia comienza en 1907, dos familias, los Capitetos y los Tontescos, se odian a muerte, pero no pueden impedir que sus primogénitos contraigan matrimonio. De esta unión nacen dos pares de mellizos. Por desgracia, poco después mueren los padres, y cada pareja compuesta por un chico y una chica, es acogida por sendas familias.

Pasados los años, década de los 30, dos de los mellizos se han casado con personas de mal carácter, mientras que la otra pareja se ha criado en el extranjero. Sin embargo, el lío empieza cuando los hermanos se reencuentran y las confusiones se suceden una detrás de otra. Ese ambiente relajado, un tanto frívolo y tontorrón, se convierte en una especie de propuesta cómica, consecuencia de los defectos del liberalismo (identificándose con la República).

La segunda película es la adaptación de una obra de teatro de Jacinto Benavente, y la historia transcurre antes y durante la Guerra Civil. Se trata de un melodrama sobre la relación entre un piloto de avión libertino, Guillermo (apodado Silvo), y una joven ciega, Magdalena, que acaba de recobrar la vista, y que huye por la proposición deshonesta de su padrastro. En esta huida se encuentra con Guillermo y, a partir de ahí, comienza su relación. El contexto histórico republicano no se define, pero es la guerra lo que acaba por redimir a los propios personajes.

Aparte de las películas dedicadas a la propia contienda, la Segunda República es un periodo vinculado únicamente a una suerte de valores frívolos y decadentes (el liberalismo), una marca que no desaparecerá con el tiempo sino a la que se recurrirá alusivamente.

Un caso curioso es, Vida en sombras (1948), de Llobet Gracia, un homenaje particular al séptimo arte. Esta es la historia de Carlos, interpretado por Fernando Fernán Gómez, que nace, casualmente, bajo una carpa, en Barcelona, durante una de las primeras representaciones del cine de los Lumiere en España, a inicios del siglo XX. Su amor por el cine le lleva a convertirse en operador de cámara a lo largo de los años

\footnotetext{
12 ELENA, Alberto, ¿Quién prohibió Rojo y Negro?, Secuencias, $n^{\circ}$ 7. Universidad Autónoma de Madrid: Instituto Universitario de Ciencias de la Educación. Madrid. 1997. pp. 61-78.

${ }^{13}$ GUBERN, Román, Raza: El ensueño del general Franco, Madrid, Ediciones 99, 1977; CAPARRÓS LERA, José María, El cine político visto después del franquismo, Barcelona, Dopesa, 1978, pp. 114-118; BERTHIER, Nancy, "Raza, de José Luis Sáenz de Heredia: una película acontecimiento", en SÁNCHEZ-BIOSCA, Vicente (coord.), España en armas: el cine de la guerra civil española, Valencia, Diputación de Valencia, 2007, pp. 53-62; CRUSELLS, Magí, "Franco un dictador de película: nuevas aportaciones a la raza", en CAMARERO, Gloria (coord.), Vidas de cine, el biopic como género cinematográfico, Madrid, T\&B Editores, 2011, pp. 239-284.
} 
siguientes. En la transición que anuncia el cambio de régimen, en 1931, anunciado por un calendario Navideño, es muy ilustrativo que se vea un primer plano de un crucifijo colgado en una pared que es en ese instante es sustituido por un cuadro con la imagen de la República mientras las voces de unos niños recitan la tabla de multiplicar. Poco después, tras haber transcurrido unos años, la mención al Frente Popular entra en relación con una situación tensa y crispada cuando se nos muestran imágenes de un mitin y una urna destrozada por un palo. Mayormente, la historia costumbrista evita tratar temas políticos y estas cuestiones son puramente simbólicas y referenciales hasta que estalla la Guerra Civil. Pero estas dos referencias no pasan del todo desapercibidas porque contienen un aspecto muy simbólico crítico con la República: el anticlericalismo republicano y la ilegitimación de las urnas de 1936, donde ganó el Frente Popular.

En el momento de estallar la guerra, Carlos y, Ana, su mujer escuchan un día en la radio el anuncio de la sublevación militar, esta es calificada, paradójicamente, como "alzamiento", aunque el noticiario es republicano y, luego, cuenta como se ha hecho un reparto de armas entre los "frentepopulistas quienes, de momento, mantienen a raya con su valor a los traidores a la República". Nuevas informaciones proporcionadas por la Generalitat darán otro parte en el que se anuncia que las milicias sindicales están reduciendo a los militares en el Cuartel de la Montaña en Madrid y en otros lugares de la península, denominando a las tropas rebeldes de facciosas. El punto de vista elegido de la emisión, el del bando republicano, sorprende, en todo caso. No era usual. Porque, además, tampoco nos indica cuál es la simpatía ideológica de Carlos. Su catolicismo nos indica que es un buen español, aunque su actitud es neutra, su amor por el cine (y su mujer) son sus verdaderas motivaciones hasta que la muerte de su mujer, imaginamos que, en manos de milicianos, le lleva a implicarse en la guerra en el bando nacional. No fue una película bien acogida por el régimen que exigía algo más militante. De hecho, la película no fue estrenada hasta 1953, en cines de programa doble y obteniendo la peor calificación posible por la censura (tercera categoría) para su comercialización ${ }^{14}$.

Ya en la década de los 50 y 60 la construcción de relatos en los que se pretende explicar las causas de la contienda aporta matices y concreciones nuevos a la hora de dibujar el periodo republicano. Entre ellos cabe destacar Cerca del cielo (1951), de Domingo Viladomat y Mariano Pombo; Lo que nunca muere (1954), de Julio Salvador; Mi calle (1969), de Edgar Neville; La paz empieza nunca (1960), de León Klimonsky; Un puente sobre el tiempo (1964), de José Luís Merino; Las últimas horas (1965), de Santos Alcocer; Tristana (1970), de Luís Buñuel; y Varietés (1971), de Juan Antonio Bardem $^{15}$.

En el marco de estos filmes hay que distinguir claramente Cerca del Cielo, Lo que nunca muere, La paz empieza nunca y Un puente sobre el tiempo. Cerca del Cielo es un filme denominado de cruzada que alcanza unas cotas enormes de carácter "triunfalista y maniqueo" 16 . El argumento se inspira en la biografía del obispo de Teruel, Anselmo Polanco, asesinado en 1939 por tropas irregulares republicanas, poco antes del final de la contienda. La primera parte del filme es la que nos interesa porque lleva a cabo un retrato confuso de las causas de la guerra inculpando a los "rojos" su inicio e imputándoles todos los crímenes perpetrados durante la guerra, en una clara

\footnotetext{
${ }^{14}$ SÁNCHEZ-BIOSCA, Vicente, p. 164.

${ }^{15}$ GUBERN, Román, "La Guerra Civil vista por el cine del franquismo", en Santos JULIÁ (dir.), Memoria de la guerra y del franquismo, Madrid, Taurus, 2006, pp. 187-193; SÁNCHEZ-BIOSCA, Vicente, 113-207 y CRUSELLS, Magí, La Guerra Civil española: cine y propaganda, Barcelona: Ariel, 2000, pp. 195-205.

${ }^{16}$ GUBERN, Román, p. 163.
} 
"demonización"17. El filme se adecua al nuevo marco de la política exterior del franquismo que quería presentarse, en plena Guerra Fría, como el máximo adalid de la lucha victoriosa contra el pérfido comunismo, destacando los crímenes del otro bando, de raíces extranjeras y con un carácter destructor de las esencias patrias ${ }^{18}$.

Interpreta a una visión sesgada de la guerra y caracteriza el periodo anterior a la misma como de nefasto.

En Lo que nunca muere, adaptación de una novela radiofónica, siguiendo el modelo inspirador de Raza (1942), retrata la historia de dos hermanos que son separados por la contienda. Uno es educado en la URSS y el otro permanece en España. Por supuesto, aunque el personaje del hermano, que ha roto con los ideales españoles, se redime al final de la trama, el periodo republicano es descrito como un marco de desorden y gobiernos irresponsables.

De la trama de La paz empieza nunca, aunque se desliza por derroteros distintos a los dos anteriores, uno llega a las mismas conclusiones. El protagonismo, esta vez, lo adquiere un falangista, López, que lidia desde la clandestinidad contra las barbaridades que están llevando a cabo los republicanos: la violencia del Frente Popular, las acciones anticlericales y los altercados, etc. Tras el final de la contienda, López es reclamado para seguir luchando contra los maquis, de ahí el título del filme, advirtiendo sobre la pervivencia de aquellos que todavía quieren subvertir y destruir el régimen instaurado. No hay duda de que se establece un continuismo de una lucha que no ha acabado con la Guerra Civil, puesto que los enemigos de la patria (los republicanos) están siempre al acecho, dispuestos a destruirla ${ }^{19}$.

Si en los filmes anteriores se habla del periodo anterior y posterior de la contienda vivida por los propios protagonistas, en Un puente sobre el tiempo se pretende llevar a cabo no solo una confirmación de ese pasado, el filme es un homenaje a los alféreces provisionales, sino educar a las nuevas generaciones en lo que aquella confrontación supuso y significa. Para ello se utiliza la figura del hijo de un antiguo alférez provisional que, por gajes de la historia, es educado en el extranjero. Regresa como periodista para escribir un artículo sobre la lucha que se ha sostenido en España contra el comunismo, pero sin estar imbuido de la auténtica fe de saber lo que ello significó para los buenos españoles. Así que los antiguos compañeros de armas del padre se empeñan en contarle la verdad de aquella confrontación. Y como se conserva bien viva la memoria por el sacrificio de aquellos hombres, ya abuelos, por parte de la sociedad $^{20}$. La breve descripción que se hace del origen de la guerra, el periodo republicano, es furibundamente oscura y gris, en la que sobresale el temor "revolucionario". El filme se integraba en los fastos propagandísticos en los que se conmemoraba el $25^{\circ}$ aniversario de la paz de Franco ${ }^{21}$.

Tanto Tristana como Varietés, en cambio, son dos películas de temáticas bien distintas a las anteriores que contienen una intencionalidad muy clara y manifiesta: construir una visión del pasado desde la perspectiva del régimen para legitimar la contienda. Por el contrario, en su apenas apoyatura histórica, tanto Tristana como Varietés confluyen en esa visión negativa indirecta que se plantea de esos años 30.

Varietés se ambienta en los años 30. Una joven y prometedora cantante de una compañía de Varietés, Ana Márquez, anhela alcanzar la fama y convertirse en la

\footnotetext{
${ }^{17}$ DI FEBO, Giuliana, "La cancelación de la República...”, p. 118.

${ }^{18}$ RICHARDS, Michael, pp. 139-158 y HEREDERO, Carlos F, La pesadilla roja del general Franco, San Sebastián, Festival Internacional de San Sebastián, 1996.

${ }^{19}$ GUBERN, Román, 1936-1939: La guerra de España, Madrid, Filmoteca española, 1986, p. 136.

${ }^{20}$ RICHARDS, Michael, pp. 159-161. Constituyeron una asociación, en abril de 1958, que se mantuvo muy activo buscando sostener una memoria viva de la cruzada para explicar a los jóvenes lo que había sucedido.

${ }^{21}$ RICHARDS, Michael, pp. 197-224 y AGUILAR, Paloma, pp. 81-188.
} 
primera cantante de la función. El filme no deja de ser una apuesta para el lucimiento de Sara Montiel como sex symbol de la época. Tristana se contextualiza en la ciudad de Toledo entre los años 1929 y 1935, y cuenta la extraña relación entre una joven inocente y su padrastro. Aunque en ninguno de los dos casos se alude a la República, en Tristana sí hay alguna escena de altercados sociales, lo esencial radica en ubicar, como en los filmes de los años 40, en este periodo de tiempo republicano las historias más controvertidas. No es coincidencia que identifique estos años 30 con el libertinaje o comportamientos sexuales poco adecuados.

A su vez Mi calle y Las últimas horas tienen aspectos singulares que acaban mostrando una mirada negativa contra la Segunda República. Mi calle es un retrato costumbrista de una calle de Madrid que abarca un amplio periodo de tiempo (desde 1906 a 1939) en el que se cuenta la historia y el devenir de diferentes personajes, ya sean de buena clase social o de los estratos más bajos. Entre ellos está la figura de un republicano, padre de familia que, aunque recibe con entusiasmo la proclamación de la República, luego se decepciona con ella. Sin duda, esta breve pincelada, aunque adquiera una connotación negativa, se enlaza con el otro filme que evoca las últimas horas de la monarquía. Las últimas horas describe los entresijos políticos, y su reflejo social, del triunfo de las izquierdas en las elecciones municipales de abril de 1931.

Aunque se ven las primeras imágenes triunfales de la victoria y de la multitud en las calles, al final, la trama concluye argumentando que la aceptación de la República se justifica con el fin de evitar una "revolución sangrienta" y una "fratricida Guerra Civil" que, finalmente, se vuelven inevitables. Así que, como afirma Tusell, y que nos sirve de conclusión, "la dictadura de Franco fue, ante todo y, sobre todo, Antirrepública"22.

Lo que explica por qué se ha ido construyendo una antiimagen republicana, donde "la propaganda franquista se dedicó sistemáticamente a denigrar"23 su memoria.

Si bien, eso no evitó un cine contestario, metafórico y crítico con ese pasado o el mismo régimen de Franco, que conseguiría esquivar la censura (en parte), como fueron La caza (1965) de Carlos Saura, El espíritu de la colmena (1973), de Víctor Erice, La prima Angélica (1974), Cría cuervos (1975), de Carlos Saura y Furtivos (1975) de José Luís Borau ${ }^{24}$.

En suma, esta retrospectiva de películas (que no es exhaustiva) nos hace ver el modo en el que el franquismo construyó este imaginario oficial del pasado marcado por la falta de autorreflexión crítica sobre las causas de la contienda y el etiquetado negativo, de una manera reiterada y manida, de los males que aquejaron a la sociedad española y que desembocaron en la guerra de España. A pesar de que el cine sobre la guerra derivó en una fallida reconciliación, en la que siempre el bando vencedor lleva la razón, desplazando así la vieja argumentación de que fue una guerra de liberación patriótica, siguió sin dejar sitio a aquellos que lucharon a favor de la República. La imagen graduaba, una vez más, una visión propagandística y didáctica sobre cómo había que asumir la perspectiva de ese pasado traumático ${ }^{25}$.

\footnotetext{
22 TUSELL, Javier, La dictadura de Franco, Madrid, Alianza, 1988, p. 15.

23 REIG TAPIA, Alberto, "La proclamación de la II República en la memoria literaria y cinematográfica", en EGIDO, Ángeles (ed.), Memoria de la Segunda República, Madrid, Biblioteca Nueva, 2006, p. 139.

${ }^{24}$ MAINER, José-Carlos y JULIÁ, Santos, El aprendizaje de la libertad 1973-1986, Madrid, Alianza, 2000, pp. 140146.

${ }^{25}$ RICHARDS, Michael, pp. 40-50.
} 


\section{0)}

\section{Los restos del naufragio republicano: la llegada de la democracia (1975-}

La muerte de Franco el 20 de noviembre de 1975 trajo consigo una paulatina e inequívoca transformación en todo el país. El régimen franquista, la democracia orgánica, vería en los meses siguientes su vaciado y desmontaje, mientras que los aparatos de control social, como la censura, iban perdiendo su poder coercitivo. Sin embargo, este proceso no sucedió de la noche a la mañana, ni España, parafraseando a Azaña, se acostó franquista y despertó democrática sino, como estima oportunamente Santos Juliá, en el seno de la sociedad española se había producido un consenso sobre ese pasado y una reconciliación que eclosionaría, estando ya preparada para ese cambio, con la Transición ${ }^{26}$. Por supuesto, en el cine, una hornada de jóvenes directores que habían visto sus trabajos, en parte, cercenados o controlados por la estrecha orientación ideológica o la censura, se atrevieron a indagar sobre una mirada de España distinta a la que se había querido presentar ante los ojos del mundo

La primera de esas películas sería Pascual Duarte (1975), de Ricardo Franco, inspirada en la novela de Camilo José Cela, La familia de Pascual Duarte. La trama es la áspera y cruda descripción de la sociedad rural española de los años 30. Aunque el filme es la radiografía de esa España trágica, sí hay algunas evidencias y señales, en positivo, sobre la instauración de la Segunda República en España. Se tuvo que pedir un permiso especial, aún en estos tiempos, para radiar un discurso del que fuera primer presidente Niceto Alcalá-Zamora. Todavía el tocar aspectos de ese pasado despertaba recelos y sensibilidades.

El siguiente filme sería Retrato de familia (1976), de Antonio Giménez Rico. Es una libre adaptación de la novela de Miguel Delibes, Mi idolatrado hijo Sisí. Aunque la novela no tiene una vocación política, al contrario, la manera en la que Giménez Rico retrata y enfoca la película configura, por primera vez, aunque desde el punto de vista de una familia conservadora, una tercera España, aquella que no quiso ni quería luchar en la contienda incivil. El largometraje estuvo teñido de una agria polémica debido a las escenas de alto contenido sexual y en el hecho de que uno de los protagonistas, Sisí, apareciera en un prostíbulo siendo menor de edad, más que por el enfoque en sí mismo ${ }^{27}$. Alabada por la crítica, salvo por ese aspecto controvertido, retrata una visión turbulenta de la España republicana de 1936, ligándola a los aspectos que explicarían el inicio de la contienda, desde un punto de vista inadmisible en las décadas anteriores. La guerra ya no era una Cruzada ni una guerra de liberación sino una guerra civil en toda regla en la que muchos sufrieron y perdieron mucho arrastrados por la vorágine belicista. Sin duda, es una película crítica con la violencia, que no tiene nada de heroísmo (así, el hijo de Cecilio, Cecil, muere de una manera accidental) y con quienes, inconscientes, vivieron al margen de los problemas sociales.

Cabe destacar, además, en el telón de fondo de la trama, una cierta mitificación de la turbulencia de los últimos meses republicanos, que ha sido analizada con rigor en recientes estudios historiográficos ${ }^{28}$. Si bien, eso refleja el modo en el que se había

\footnotetext{
${ }^{26}$ RICHARDS, Michael, pp. 270-279 y MAINER, José-Carlos y JULIÁ, Santos, pp. 53-60.

${ }^{27}$ Archivo General de la Administración, expediente rodaje, Caja 36/5207; “¿Corrupción de menores?”, ABC, 23 de septiembre de 1976, p. 3; GUBERN, Román, La censura. Función política y ordenamiento jurídico bajo el franquismo (1936-1975), Barcelona, Península, 1981, p. 126-135. Prevaleciendo, incluso, una censura extraestatal procedente de la propia sociedad conservadora; SÁNCHEZ SALAS, Bernando, "Retrato de familia", en Julio PÉREZ PERUCHA (ed.), Antología crítica del cine español (1906-1995), Madrid, Cátedra, 1997, p. 747.

${ }^{28}$ GONZÁLEZ CALLEJA, Eduardo y NAVARRO, Rocío (eds.), La España del Frente Popular, Comares, Madrid, 2011; GONZÁLEZ CALLEJA, Eduardo, Cifras Cruentas. Las víctimas mortales de la violencia sociopolítica en la Segunda República Española (1931-1936), Comares, Madrid, 2015 y MARTÍN RAMOS, José Luis, El Frente Popular. Victoria y derrota de la democracia en España, Pasado \& Presente, Barcelona, 2015.
} 
influido en el imaginario colectivo, aun cuando el filme cabría definirlo como una mirada crítica con el discurso oficial que el régimen franquista había querido imponer sobre el origen y consecuencia de la guerra ${ }^{29}$.

En otro ámbito podríamos agrupar una serie de filmes que, aunque ambientados en esos años 30, nada añaden de interés al tema de la época republicana como fueron Guerreras verdes (1976) de Ramón Torrado, una apología sobre la Guardia Civil; Gusanos de Seda (1976), de Francisco Rodríguez; y Parranda (1977), de Gonzalo Suárez.

En otro grupo estarían los filmes militantes de izquierdas como Borrasca (1977), de Miguel Ángel Rivas, denuncia del caciquismo imperante en España en los años 20 hasta alcanzar la instauración de la Segunda República, haciendo una lectura en la que todo continúa igual; y Tierra de rastrojos (1979), de Antonio Gonzalo, un filme de tendencia anarquista, en el que se hace una interesante radiografía del campo andaluz, entre el retrato social y el idealismo, y en el que la época republicana se erige con un protagonismo propio.

Sin duda, Mi hija Hildegart (1977), de Fernando Fernán Gómez, es un filme hijo de su tiempo que, aunque tuvo un notable éxito en taquilla (más de un millón) ${ }^{30}$, no es de los trabajos que se consideran más logrados de su labor como director. La historia se apoya en la novela Aurora de sangre del periodista Eduardo de Guzmán ${ }^{31}$. Es la historia verídica de Aurora Rodríguez quien asesinó a su hija Hildegart, una joven abogada de dieciocho años, que se había convertido en una afamada escritora y activa política, vicepresidente de las Juventudes Socialistas, sobre todo en los años de la Segunda República. El filme pretende ser una alegoría, en estos tiempos de la Transición, sobre los peligros del fanatismo, incluso aquellos que defienden altos ideales como puede ser la liberación de la mujer o ya, mismamente, los valores democráticos. Tal y como confirma el crítico de cine Ramón Freixas, "curioso es, así mismo, observar que ciertos apuntes históricos fuerzan un paralelismo con la realidad de 1977"32.

Fernán Gómez plantea el tema desde una singular intelectualidad que, en parte, es lo que lastra la narración fílmica. Pero, sin duda, el cartel publicitario del filme ayudó mucho a atraer al público, al hacer referencia a una temática sexual, aunque no fuera la cuestión principal del mismo (tanto es así que los últimos coletazos de la censura le reconvinieron en algunas escenas aunque, para cuando se estrenó, aquella ya había desparecido y no tuvo que realizar ningún corte $^{33}$ ). La visión que se ofrece del tiempo republicano no es del todo negativa, se desprende de esos mitos en los que se presentaba como una época turbulenta y caótica, aunque sí se revela que existían corrientes de pensamiento extremistas que trajeron consigo el drama de la violencia. El filme, en mi opinión, no ha sufrido tanto por el paso del tiempo como pudiera parecer, aunque el estilo frío y depurado que utilizó el director no le hace ser una película de referencia de este periodo, si bien, sin duda alguna, es digno de ser destacado.

El siguiente filme, Tierra de rastrojos (1979), de Antonio Gonzalo, basado en la novela homónima de Antonio $\mathrm{Cano}^{34}$, retrata la vida campesina a inicios del siglo XX,

\footnotetext{
${ }^{29}$ SOUTHWORTH, R. Herbert, El mito de la cruzada de Franco, Barcelona, Plaza y Janés, 1986; CAZORLA SÁNCHEZ, Antonio, Las políticas de la victoria, Madrid, Marcial Pons, 2000; MORALES MUÑOZ, Manuel (ed.), La Segunda República. Historia y memoria de una experiencia democrática, Málaga, Diputación de Málaga, 2004 y EGIDO LEÓN, Ángeles (ed.), Memoria de la Segunda República. Mito y Realidad, Madrid, Biblioteca Nueva, 2006.

${ }^{30}$ Datos del Ministerio de Cultura: www.mcu.es (1.169.543 de espectadores) [consultado: 28-2-2016]

${ }^{31}$ GUZMÁN, Eduardo de, Aurora de sangre, Madrid, Rollán, 1956.

32 FREIXAS, Ramón, "Entre la convención y la insumisión", en ANGULO, Jesús y LLINÁS, Francisco (eds.), Fernando Fernán-Gómez. El hombre que quiso ser Jackie Cooper, San Sebastián, Patronato Municipal de Cultura, 1993, p. 74.

${ }^{33}$ Archivo General de la Administración, expediente rodaje, Caja 36/5250.

${ }^{34}$ GARCÍA CANO, Antonio, Tierra de rastrojos, Sevilla, Editorial Sevillana, 1975.
} 
incluyendo el importante momento de la llegada de la Segunda República y el impulso de la reforma agraria, hasta la Guerra Civil y la posterior represión franquista. El filme tuvo su propia historia ya que fue distribuido de forma irregular, recibiría críticas muy positivas en ese momento de su estreno ${ }^{35}$, en ciudades como Sevilla o Bilbao, para luego reestrenarse en 1998. Al margen de esta historia particular, Tierra de rastrojos se erige como una interesante radiografía de la dura vida campesina en Andalucía, a pesar de su idealización del perfil de las izquierdas -el autor de la novela era anarquista-, en una manida lectura de las derechas terratenientes, incluida la Iglesia y la Falange, frente a las izquierdas reformistas que fueron aplastadas durante la contienda ${ }^{36}$.

Una cuidada ambientación en un pueblecito de Sevilla, incluida una banda sonora original, alejada del folclorismo del cine andalucista del régimen franquista, y una fotografía de enorme significación, vienen descompensadas por una narración y un dibujo de sus personajes principales no tan firmes, pero que no restan valor a su carácter pseudodocumental.

Aun así, es revelador el modo en el que retrata la época republicana, esbozando los sueños de cambio y reformismo que, por desgracia, no acabaron de cuajar. La Segunda República no refleja la violencia o el desorden sino más bien una época de ilusiones rotas para una masa campesina sin tierras y que vivía en unas condiciones de vida miserables de las que no podía escapar. El fatalismo y amargura finales de la película, de todos modos, ya no respondían, en la época de su realización, a las verdaderas condiciones del campo andaluz. Y, tal vez, fuera eso lo que no acabara de gustar, aparte de la apelación a la represión franquista, un elemento novedoso (ausencia, claro está, en el cine del régimen) que rompía el amargo silencio que había afectado sobremanera a las comunidades rurales duramente represaliadas ${ }^{37}$.

En la década de los 80, a pesar de que se acercaba la conmemoración del 50 aniversario del inicio de la contienda, el final del primer régimen democrático estuvo cubierto de un espeso y llamativo silencio. La consecución por parte del PSOE de la jefatura del Gobierno no vino acompañada por la revitalización de un impulso de políticas de la memoria, como pudiera haberse creído, sino todo lo contrario. El mismo presidente del Gobierno, Felipe González, convino en pasar página a ese incómodo pasado. Aunque eso fue duramente criticado, no evitó que se diera lugar a algunas producciones de interés que se referían a la guerra y, de una manera tangencial, a la Segunda República. Entre estas habría que señalar La plaza del diamante (1982), de Francesc Betriu, Casas Viejas (1983), de José Luis López del Río, Réquiem por un campesino español (1985), del mismo Betriu, Dragon Rapide (1986), de Jaime Camino, Pasos Largos, el último bandido andaluz (1986), de Rafael Moreno Alba y El señor de los llanos (1987), como coproducción con Venezuela, de Santiago San Miguel.

El primer filme, La plaza del diamante, se basa en la novela La plaça del diamant de Mercé Rodoreda. La protagonista Colometa es una tímida muchacha del barrio barcelonés de Gracia. Allí conoce al que será su marido, Quimet, un joven impulsivo. La llegada de la República anuncia el distanciamiento emocional que comienza a influir en la relación entre Colometa y Quimet, tras el nacimiento de sus hijos. La Guerra Civil acabará afectando a la humilde familia, con la muerte de Quimet, y la miseria y las represalias de la posguerra le obligarán a resignarse y rehacer su vida.

\footnotetext{
${ }^{35}$ MILLAN, Fernando, "Tierra de rastrojos", Nueva Andalucía, 17 de marzo de 1980; MERIKAETXEBARRIA, Antón, "Tierra de rastrojos", Egin, 14 de junio de 1980; MARTÍNEZ, Ignacio, "El rigor de lo rural", La voz de Asturias, 13 de diciembre de 1980 y SANCHIS, Vicente, "Tierra de rastrojos", Levante, 14 de agosto de 1984.

${ }^{36}$ MALEFAKIS, Edward, Reforma agraria y revolución campesina en la España del siglo XX, Barcelona, Ariel, 1972 y TÉBAR HURTADO, Javier, Reforma, revolución y contrarrevolución agrarias, Barcelona, Ediciones Flor del Viento, 2006.

${ }^{37}$ RICHARDS, Michael, pp. 297-298. Llegándose a producir las primeras exhumaciones.
} 
Como se ha dejado entrever en esta breve descripción de su argumento, el filme es un drama emocional que se convierte en una reflexión humana sobre el sufrimiento y el dolor vividos desde el punto de vista femenino. El periodo de la Segunda República apenas destaca frente a lo que va a ser el efecto destructor y terrible de la guerra en la vida de los protagonistas. Una vez más, se desvelan los traumas de la guerra, dejando de manera harto imprecisa el periodo anterior a ella, sin desvelar nada que nos pueda servir para resaltar sobre la caracterización (positiva o negativa) de este periodo ${ }^{38}$.

Del siguiente filme, Casas Viejas (1983) cabría señalar su referencia directa a un hecho singular e importante para el devenir de la historia republicana, la matanza de Casas Viejas el 10 de enero de 1933, con un saldo negativo importante de víctimas civiles $^{39}$. Pero, por desgracia, no hay copia disponible del filme de José Luis López del Río en la Filmoteca española, por lo que no podemos llevar a cabo una valoración del mismo.

Las dos siguientes películas nacen en este marco de la conmemoración de la Guerra Civil. Betriu, al igual que con su anterior filme, se adentra en el seno de la sociedad española, adaptando la conocida novela Réquiem por un campesino español, de Sender ${ }^{40}$. El filme cuenta la historia de un campesino español, Paco "el del molino", y su notorio compromiso con las desigualdades sociales y miseria existente en el campo. La llegada de la Segunda República permite proceder a una reforma agraria que beneficie a aquellos campesinos que viven en la miseria más absoluta, a pesar de las reticencias de los poderes locales tradicionales del lugar. Pero el inicio de la guerra derivará en la llegada al pueblo de una partida de falangistas que darán un escarmiento a los lugareños y a sus sueños de reforma, provocando una dura y sangrienta represión, que afectará también a Paco. La película tuvo una buena acogida por ser una de las pocas producciones que se realizarán conmemorando el inicio de la contienda y, sobre todo, por tratar directamente el tema de la represión franquista ${ }^{41}$.

En cuanto a la representación de la época republicana se vislumbra como un panorama lleno de ilusiones y sueños, de un intento loable de cambio y transformación de la sociedad que acabará con las injusticias sociales tan fuertemente imperantes en el campo. Finalmente, todo esto se verá truncado por la violencia ejercida por el bando nacional.

Réquiem por un campesino español se convierte en una hábil, aunque contenida, mirada y radiografía social del campo. En sus virtudes, se halla la construcción de un relato coherente, firme y aleccionador sobre el pasado. Un recordatorio, aunque no sea demasiado profundo, sobre la importancia del periodo a la hora de intentar cumplir con las ansias, esperanzas y necesidades de los millones de agricultores españoles que vivían en unas condiciones tan miserables. Así escribe Mercedes Cabrera: "Sobre esta sociedad todavía mal comunicada y poco integrada, de localismos y vida provinciana, con una cultura política asociativa y participativa escasamente desarrollada, se dispuso la II República a reformar, trasformar y revolucionar casi todo" ${ }^{42}$. Y la manera en la que este periodo histórico se ve destruido por el franquismo.

\footnotetext{
${ }^{38}$ MIRAMBELL, Miquel, "Barcelona y la plaza del Diamante", Film-Historia, núm. 3 (1994), pp. 237-250.

39 PRESTON, Paul, La destrucción de la democracia en España, Madrid, Ediciones Turner, 1978, pp. 140-142 y PAYNE, Stanley, G., La primera democracia española. La Segunda República, 1931-1936, Barcelona, Paidós, 1995, pp. 155-160.

${ }^{40}$ SENDER, Ramón J., Réquiem por un campesino español, Barcelona, Destino, 2006.

41 "Un Réquiem que no logra convencer", El Correo Catalán, 14 de septiembre de 1985; GUARNER, José Luís, "Réquiem por un campesino español”, La Vanguardia, 30 de septiembre de 1985 y RUIZ, Jesús, "Réquiem por un campesino español”, El Correo Catalán, 27 de septiembre de 1985.

42 CABRERA, Mercedes, "Proclamación de la República, Constitución y Reformas", en JULIÁ, Santos (coord.), República y guerra en España (1931-1939), Madrid, Espasa, 2006, p. 45.
} 
El otro filme que trata sobre el origen de la Guerra Civil es el antes citado Dragón Rapide, de Jaime Camino, cuya filmografía está muy vinculada a esta singladura histórica. El film se ambienta en el mes de julio de 1936, en los prolegómenos de la contienda, cuando los conspiradores necesitan del concurso de un dubitativo Franco para proceder a dar el golpe de Estado. Se desvelan así los entresijos de la trama, apoyada por empresarios, y del periplo que supuso el alquiler del avión que permitió a Franco volar desde las islas Canarias a Tetuán y hacerse cargo del mando de la rebelión en Marruecos.

La Segunda República es un marco secundario de la historia, si bien se describe, desde esa visión pesimista y apocalíptica de las derechas, como un régimen del desorden y de quema de iglesias. Sin duda, la radicalización de las derechas, así como ciertas acciones de grupos radicales de izquierdas, generó las condiciones que justificaron para estos militares su trama golpista que desencadenó una terrible lucha incivil. Lo más destacado de su trama es el retrato, nada heroico, por otro lado, de Franco, su lado humano, alejado de los clichés propagandísticos con los que se quiso adornar su figura ${ }^{43}$.

Finalmente, esta década cabe cerrarse con dos filmes menores, tanto en su estilo como en su carácter histórico como son Pasos Largos, el último bandido andaluz y El señor de los llanos. El primero es la biografía de un personaje verídico, Juan Mingolla Gallardo, conocido como Pasos largos, cazador furtivo que vivió cerca de Ronda entre 1873 y 1934. Una parte de sus andanzas se contextualiza en el periodo republicano. Así, se alude a las reivindicaciones campesinas y se describe la pobreza imperante en el campo andaluz ${ }^{44}$. Lo que nos muestra que fue un periodo de enorme efervescencia política y social. El otro filme, El señor de los llanos, se ambienta en los años 30, y es la historia de amor entre un indiano y una prostituta. En cuanto al contexto republicano apenas si hay alguna alusión directa al mismo ${ }^{45}$.

\section{Entre el ideal perdido y el olvido: El regreso al pasado republicano (1991- 2008)}

En los años 90, el contexto político que se estaba fermentando en España con el declive socialista, en el que se auguraba una victoria del Partido Popular, como así sería, influyó de manera indirecta en un renovado interés por el periodo republicano ${ }^{46}$. En 1998, se estrenaría el filme Pasiones rotas (1995), del director irlandés Nick Hamm, que contaba con un elenco de actores y actrices españoles, así como otros de talla internacional. Rodado en 1995, había tenido que aguardar tres años para ver la luz, imaginamos debido a su escasa calidad, aprovechando este renovado interés por revitalizar la memoria histórica. El largometraje, inspirado libremente en la novela autobiográfica de Kate O’Brian titulada Mary Lavelle ${ }^{47}$, discurre en Asturias en los

\footnotetext{
${ }^{43}$ CRUSELLS, Magí, La Guerra Civil..., pp. 231-234.

${ }^{44}$ ALVAREZ REY, Leandro y LEMUS LÓPEZ, Encarnación (eds.), Historia de Andalucía Contemporánea, Huelva, Universidad de Huelva, 1998 y ALVAREZ REY, Leandro (coord.), Andalucía y la Guerra Civil. Estudios y perspectivas, Sevilla, Diputación de Sevilla-Universidad de Sevilla, 2006

${ }^{45}$ RICHARDS, Michael, pp. 316-317. Respecto a la televisión se puede decir que tuvo mucho interés en el retrato social de los años 20 y 30, con Los gozos y las sombras (1982), adaptada de la novela de Gonzalo Torrente Ballester, y Crónica del alba (1983), el docudrama El balcón vacío (1984), Vida privada (1987), Lorca, muerte de un poeta (1987), Vísperas (1987), El olivar de Atocha (1989), Los jinetes del alma (1990) y La forja de un rebelde (1990).

46 JULIÁ, Santos, "El retorno del pasado al debate parlamentario (1996-2003)", Alcores, núm. 7 (2009), p. 235.

47 O'BRIEN, Kate, Mary Lavelle, Barcelona, Edhasa, 1990. De hecho, la novela transcurre en los años 20 y se ambienta en la localidad vasca de Portugalete.
} 
meses previos a la contienda. Cuenta la historia de una institutriz irlandesa que llega al seno de una familia asturiana de alta posición para educar a sus hijas.

A partir de su enamoramiento de Francisco, el hijo casado, Mary se ve enfrascada en la tensión que está desgarrando España, a la par que siente una enorme pasión por el propio país y su naturaleza trágica.

Ahora bien, la película no deja de ser una visión extranjera de tales acontecimientos, cargada de clichés (la fascinación de los españoles por la sangre, encarnada en una corrida de toros), prejuicios (los perversos curas) y contradicciones (violencia social permanente que justifica, precisamente, la acción golpista) que desvelan una imagen de la época equívoca, aunque el filme sea pretendidamente prorepublicano. De hecho, se asemeja mucho a lo que escribe Rafael Cruz sobre parte de los mitos que envolvieron el clima social reinante en los últimos meses de su existencia, por lo que supuestamente "la insoportable gravedad de la violencia, la amenaza de la revolución social, la complicidad o la ineptitud de los gobernantes, la ofensiva del fascismo, la deslealtad de los militares, la maldad, en definitiva de muchos hombres, se convirtieron en el eje de las explicaciones de la guerra, un acontecimiento dramático y necesario para restaurar la España católica o destruir la democracia"48.

Parte de lo que vemos, y tal y como se nos presenta en diversas escenas, da lugar a creer que la República fue víctima precisamente de estos condicionantes de brocha gorda. En el filme, este discurso es más confuso todavía, puesto que tampoco se desvelan las claves de la injusticia social reinantes. Además de malograrse este acercamiento a la última etapa de la república, el filme es artísticamente mediocre, no teniendo casi impacto entre la crítica ni entre los circuitos de distribución comerciales, con una escasa afluencia de público ${ }^{49}$.

Paralelamente se estrenaría Mararía (1998), de Antonio Betancor, adaptación de la novela de Rafael Arozarena, ambientada en las islas Canarias, en la que relata una tortuosa historia entre una mujer del lugar y un médico. Aunque el drama se desarrolla, principalmente, en el contexto republicano, apenas si se aprecia nada destacado sobre ello. De ahí que el filme, a pesar de su interesante factura y excelente puesta en escena, no nos sea relevante para este estudio. En cambio, un año más tarde se estrenaría $L a$ lengua de las mariposas (1999), de José Luís Cuerda, seguramente el filme más acabado e interesante que nos desvela las claves e ideales de aquel periodo luminoso, tan lleno de esperanzas, que se inclinó fatalmente hacia la explosión más absurda de violencia. El filme se inspira en el libro de relatos de Manuel Rivas recogidos en la obra ¿Qué me quieres amor ${ }^{50}$, dando pie a una estructurada narración apoyada en la relación de un niño, Moncho, y su maestro, don Gregorio.

La lengua de las mariposas se ambienta en los meses anteriores al estallido de la contienda. En ella se lleva a cabo un fresco de la Galicia rural y se trasmite con suma sutileza y habilidad lo que Sandie Holguin denomina como República de ciudadanos ${ }^{51}$. Representa el fallido intento por parte del régimen democrático de construir una sociedad moderna, a través de una apuesta clara y directa por la educación y el desarrollo de la cultura. El esfuerzo se materializó con una reforma educativa inspirada en las aportaciones de la Institución Libre de Enseñanza que, por desgracia, se vio truncada por la Guerra Civil y la posterior depuración que se hizo de la sociedad

\footnotetext{
${ }^{48}$ CRUZ, Rafael, En el nombre del pueblo, Madrid, Siglo XXI, 2006, p. 332.

49 TORRES, Augusto M., "Una torpe producción", El País, 24 de enero de 1999; PUYÓ, Carmen, Memorias de juventud", Heraldo de Aragón, 26 de enero de 1999 y BELINCHÓN, Gregorio, "Pasiones rotas", Cinemanía, núm. 41, febrero de 1999.

${ }^{50}$ RIVAS, Manuel, ¿Qué me quieres amor?, Punto de lectura, 2000.

${ }^{51}$ HOLGUÍN, Sandie, República de Ciudadanos, Barcelona, Crítica, 2003.
} 
española a todos los niveles ${ }^{52}$. De este modo, la relación entre don Gregorio y el joven Moncho viene ligada a esta senda abierta por la República de desterrar el caciquismo o bien la intolerancia, en todos los sentidos, haciendo que las futuras generaciones crecieran en libertad y con una clara conciencia de sí mismas. Pero el temor y la inquietud que tales ideas provocaron en los sectores de la sociedad más reaccionarios a aceptarlas, hicieron que la viabilidad del proyecto republicano se viniese abajo, amén de otras cuestiones como la reforma agraria, el anticlericalismo, malestar de los militares, etc. La historia es una delicada joya, llena de luminosidad, candidez e inocencia que se van destilando a través de los ojos del joven Moncho hasta que, conocida la noticia de la rebelión en Marruecos, don Gregorio y todas aquellas autoridades republicanas son detenidos. Se quiebra, así, ese sueño. La lengua de las mariposas es una entrañable y paternal lección para la sociedad democrática actual, revelando aquel periodo de sueños $\operatorname{rotos}^{53}$.

El trabajo de Cuerda tuvo una muy buena acogida por el público, con un 1.160.291 de espectadores, y recibió el Goya al mejor guion adaptado para Rafael Azcona $^{54}$. La crítica le sería muy favorable, entre las que cabe citar la de Mirito Torreiro, que escribe con elogio: “(...) se comporta como una ficción reconfortante para un sector amplio del público, como la reivindicación de una memoria que es la de quienes, aun sin haber nacido, también perdimos aquella guerra" 55 . Begoña del Teso destaca, por ejemplo, los valores que plantea el filme, en la añoranza de "lo que pudo ser y no fue, aquella esperanza en los años de la República, una esperanza de libertad y modernidad que ya estaba, por ejemplo, en Belle epoque (...)"56.

Siguiendo esa misma línea, si bien desde otro enfoque, Manuel Gutiérrez Aragón se inspiró en unos hechos sucedidos en la localidad guipuzcoana de Ezkioga durante el primer verano de la instauración de la Segunda República para tratar la cuestión religiosa, otro de los aspectos claves para entender este contexto histórico. Pero, aunque toda obra de ficción es libre de tomarse ciertas licencias creativas, el filme de Gutiérrez Aragón se vio lastrado porque no fue capaz de emocionar ni de trasmitir un mensaje claro y porque su veracidad histórica, a pesar de la insistencia del director, deja mucho que desear como pasaré a comentar.

Al margen de que Visionarios es un filme deshilachado narrativamente, el relato histórico está trufado de fuertes inexactitudes históricas que dañan terriblemente el tejido veraz del relato. El comportamiento de algunos de los visionarios en modo alguno corresponde a lo que podría considerarse propio de videntes católicos. O lo que se convertirá, ya, en un pasaje oscuro cuando, por su laicismo, el maestro de Ezkioga aparece asesinado. No sólo parece que hay una remisión a ciertos orígenes violentos vascos, sino que para colmo de males eso nunca llegó a suceder. A su cierre, sobredimensiona tanto la importancia de los hechos de Ezkioga en el tiempo que los utiliza para explicar la causa de la Guerra Civil de una manera forzada y esquiva. El filme pasó bastante desapercibido y fue recibido de manera fría. Y no consigue ni trasmitir un mensaje claro frente a los fanatismos ni tampoco es capaz de sacar

\footnotetext{
52 PÉREZ GALÁN, Mariano y PUELLES BENÍTEZ, Manuel de, La enseñanza en la Segunda República, Biblioteca Nueva, Madrid, 2011; COSTA RICO, Antón, Escolas e mestres, Santiago de Compostela, Xunta de Galicia, 1989; OSTOLAZA ESNAL, Maitane, El garrote de la depuración. Maestros vascos en la guerra civil y el primer franquismo (1936-1945), San Sebastián, Ibaeta Pedagogía, 1996; MORENTE VALERO, Francisco, La depuración del magisterio nacional (1936-1943), Valladolid, Ámbito Ediciones, 1997.

53 BARRENETXEA MARAÑÓN, Igor, "II República, cine y memoria histórica", Cuadernos republicanos, invierno de 2011, núm. 75, pp. 119-130

${ }^{54}$ Datos del Ministerio de Cultura (http://www.mcu.es/homencu.html) [consultado: 20-9-2014]

55 TORREIRO, Mirito, “Arqueología de supervivientes”, El País (El espectador), 26 de septiembre de 1999.

${ }^{56}$ DEL TESO, Begoña, “Don Gregorio no pega”, Diario Vasco (Festival), 24 de septiembre de 1999.
} 
provecho a la lección que deberíamos haber aprendido de asumir la sensibilidad religiosa de la sociedad ${ }^{57}$.

En el resto de producciones que se pueden incluir en este marco histórico sobre republicanos, la atención dedicada al periodo de paz es mucho menor. En Una pasión singular (2002), Antonio Gonzalo, igual que ya lo hiciera en Tierra de rastrojos, ya analizada, lleva a cabo una radiografía del campo andaluz a través de la figura de Blas Infante (1885-1936), el padre del andalucismo. La Segunda República aparece de forma tangencial y se describe como una época malograda para la deseada y necesaria reforma agraria, se trata brevemente el suceso de Casas Viejas y el impulso dado al Estatuto de Andalucía, frustrado como todo lo demás por el triunfo de las fuerzas sublevadas. Blas Infante acabaría siendo fusilado el 11 de agosto de 1936.

El lápiz del carpintero (2003), de Antón Reixa, otra adaptación literaria del escritor gallego Manuel Rivas, cabría ya incluirla dentro del nuevo marco de filmes que van a versar sobre la represión franquista y la posguerra, como Trece rosas rojas, La buena nueva (2008), Los girasoles ciegos (2008), Pan Negro (2010), La voz dormida (2011). Aunque no sea un filme logrado del todo, sí es una referencia a la hora de valorar la suerte de los miles de intelectuales, republicanos o personas de izquierdas fieles a la República en Galicia. Aunque he estimado la representación cinematográfica de la represión como otro campo diferente de estudio al de la República en paz, en las primeras escenas sí hay algunas menciones claras a ella ${ }^{58}$.

Como en el resto de filmes, la Segunda República fue un periodo de grandes sueños y retos como el de lograr un Estatuto para Galicia, como ya lo consiguiera Cataluña en 1932, al que se alude en estas imágenes. Fue una época de mucha efervescencia política, pero no hay que entenderla como un marco revolucionario como hicieron las derechas, de cambios y de una transformación profunda de la sociedad que no pudo completarse.

Las diversas causas que impidieron que este régimen pudiera consolidarse fueron variadas. Ya hemos podido comprobar como hay filmes que las achacan a la cuestión agraria, otros a diversas cuestiones de antagonismos políticos pero, sobre todo, se insiste en la cuestión religiosa. Esta casuística se valorará en La buena nueva (2008), de Helena Taberna, que al igual que en el filme anterior transcurre principalmente tras el estallido del conflicto; o en la dedicada a la figura de San José María Escribá de Balaguer, Encontrarás dragones (2011), de Roland Joffé. El contexto republicano del periodo anterior a la guerra apenas si es señalado, si bien incide en el problema religioso que se vivía en la sociedad, entre la efervescencia anticlerical, dispuesta por las leyes laicistas de la República y la reacción de los grupos conservadores en defensa de una serie de valores y de aspectos vinculados a las esencias patrias.

De todos modos, ambos largometrajes persiguen fines bien distintos en sus planteamientos. Mientras que el de Taberna es un homenaje a las víctimas de la represión y analiza los perversos comportamientos humanos que nada tienen que ver con las creencias religiosas (por mucho que se amparen en ellas), el de Joffé se construye inspirándose en la etapa de juventud del creador del Opus Dei y su

\footnotetext{
57 CARCEL ORTI, Vicente, La persecución religiosa en España durante la Segunda República (1931-1939), Madrid, Ediciones Rialt, 1990; CHRISTIAN, William A. Jr., Las visiones de Ezkioga. La Segunda República y el Reino de Cristo, Barcelona, Ariel, 1997; MARTÍ GILABERT, Francisco, Política religiosa de la Segunda República española, Pamplona, EUNSA, 1998 y ALVAREZ TARDÍO, Manuel, Anticlericalismo y libertad de conciencia. Política y religión en la Segunda República Española (1931-1936), Madrid, Centros de Estudios Políticos y Constitucionales, 2002.

${ }^{58}$ BARRENETXEA, Igor, "Cine, represión y memoria histórica", III Encuentro de jóvenes investigadores de Historia Contemporánea, Universidad del País Vasco, del 13 al 16 de septiembre de 2011, Vitoria-Gazteiz
} 
experiencia durante la Guerra Civil. En ambos casos, su recepción fue discreta, si bien ambos tocan aspectos históricos de cierta trascendencia para la memoria social.

\section{A modo de conclusión}

“¿Qué tendrá la República que no se olvida? La República encarnó el sueño de la libertad, de la igualdad, de la justicia, tan antiguo en la historia de la humanidad como la misma lucha bíblica entre Caín y Abel"59. Tal significado diagnóstico de Ángeles Egido, por desgracia, no responde del mismo modo en lo que es la recreación de este periodo de tiempo en el cine. Hemos podido comprobar como la historia de la República ha sido bastante poco tratada en el cine o bien de manera desigual. Cuando lo ha sido, ha venido favorecida por ciertos clichés pero, sobre todo, por su estrecha vinculación a la Guerra Civil española, por lo que su retrato histórico siempre ha sido de un encaje bastante difícil.

Durante la primera etapa, en el periodo que abarca toda la existencia del franquismo, de 1939-1975, el etiquetado negativo que se hizo de la época republicana fue muy intenso. En un primer momento se negó su existencia, lo hemos podido ver en filmes como Fortunato o Cerca del Cielo. Y se veía subrayado por aspectos tremendamente negativos, pobreza, tensión social, comunismo, quema de iglesias, una constante que se manejaría en otros filmes como La paz empieza nunca, Lo que nunca muere, Las últimas horas, por mencionar algunos de los trabajos más señalados, en los que se alude a la época republicana, aunque no se perfile directamente.

Este difuso pero oscurantista retrata, sin duda, daba pie al régimen franquista de justificar en todo momento la causa legítima de la contienda para el bando vencedor, el franquismo, que en modo alguno podría ponerse en tela de juicio, apuntando posibles virtudes a la democracia republicana. En este sentido, el mensaje era claro y firme: la Segunda República fue la responsable de la cruenta lucha ocurrida entre los españoles. Y el cine no dejaba de aludir a ello, aunque hubiera propuestas cinematográficas de tinte conciliador, según lo entendía el régimen, sin cuestionar en ningún momento su legitimidad y triunfo. Y aquellos que habían militado en el bando republicano siempre acababan por asumir su parte de culpa, admitiendo así la superioridad moral del bando nacional.

En una segunda etapa, entre 1975-1991, la República vino marcada por este nuevo contexto surgido tras la Transición. El panorama se vio enriquecido por este impulso político en el que se derribaron las barreras de la censura y en el que existió un ansia terrible de encarar el pasado. Aun así, el periodo republicano quedaba inmerso en este marco histórico de amplio recorrido que retrataba las contradicciones o bien los problemas de la sociedad española. De este modo, nos encontramos con el filme Retrato de familia, que destacaba la existencia de una tercera España previa a la contienda. Si bien, perfilaba todavía el periodo republicano como un marco de violencia y terribles confrontaciones sociales. También, sobresale Mi hija Hildegart, un filme que pretendía ser una advertencia contra los fanatismos pero que recordaba, a su vez, la rica efervescencia política de aquellos años 30 y el impulso dado al feminismo, todo ello truncado con el franquismo. O las dos miradas llevadas a cabo en Tierra de rastrojos y Réquiem por un campesino español sobre el problema agrario, que la República pretendió resolver, y la mala situación del campesinado español. El resto de filmes de

\footnotetext{
${ }^{59}$ EGIDO, Ángeles, "Historia de una desmemoria", en EGIDO, Ángeles (ed.), Memoria de la Segunda República, Madrid, Biblioteca Nueva, 2006, p. 23.
} 
este periodo pasan por los años 30 sin destacar demasiados aspectos de la época republicana.

Una tercera etapa, entre 1991 hasta la actualidad, vendría marcada por el intento de recuperar la memoria histórica con largometrajes como los malogrados Pasiones rotas y Visionarios, la emocionante e idealizadora La lengua de las mariposas, estos tres señalados que se desarrollan sobre el tiempo republicano, así como El lápiz del carpintero, Una pasión singular, La buena nueva o Encontrarás dragones, que aluden más incidentalmente a ella.

De todo ellos, sólo destaca La lengua de las mariposas, por su calidad artística y por su aceptación entre el público, es la que mejor capta las esencias modernizadoras de la República. Es cierto que en este registro de temáticas se pueden descubrir los aspectos más esenciales que marcaron el fracaso republicano como sería el problema agrario, el conflicto religioso, el contencioso educativo, incluso, la cuestión militar en Dragon Rapide. Pero aún faltan muchos otros aspectos que abordar alejados de los prejuicios o las lecturas conservadoras en las que se intensifica de manera exagerada el peso de la intransigencia (religiosa o política), la violencia o las tensiones sociales existentes en este marco. Puesto que si la República fracasó no vino por su incapacidad de resolver los problemas que había heredado de la monarquía sino por la sublevación militar, que impediría que tales cambios fueran conducidos de una manera adecuada, en el marco del Estado de derecho.

La Segunda República, por lo tanto, es encarnada desde la ficción de una manera dual, negativa, entre la mitificación de la turbulencia de pretendido fracaso anunciado, y el idealismo postrero, presentado con la amargura nostálgica de un tiempo frustrado por las circunstancias (con diversos matices). Pero no fue ni una cosa ni otra. La República sencillamente fue la prueba del primer régimen democrático que no tuvo tiempo de madurar en una sociedad atrasada en el que las fuerzas de la reacción y la revolución acabaron por determinar su signo amargo y en la que la concepción de los idearios políticos, se entendieron desde la confrontación y no desde la causa común que debía haber sido las necesidades de cambio de la sociedad española. Lamentablemente, el cine, constituye un gran constructo de imaginarios sociales que todavía tiene que ayudar a desterrar ciertos mitos impostados por el franquismo y favorecer la comprensión (moral, humana e histórica) de aquel quinquenio.

IGOR BARRENETXEA estudió Magisterio e Historia en la Universidad del País Vasco. Se doctoró en marzo de 2014 en la misma universidad en Historia Contemporánea. Actualmente es profesor de Historia y Geografía en enseñanzas medias y prosigue con su labor de estudio en el campo de las relaciones de historia y cine, tanto en el caso español como a nivel internacional. Entre sus múltiples publicaciones en revistas y libros se destacan las más recientes como el artículo "“Más allá de la imagen. El asesinato de

Carrero Blanco en la memoria audiovisual", Patrick Eser y Stefan Peters (ed.), El atentado contra Carrero Blanco como lugar de (no) memoria. Narraciones y representaciones culturales, Iberoamericana

Vervuert, 2016, junto a Santiago de Pablo, "Tata mía (1986) o el espíritu de la Transición”, Aportes.

Revista de Historia Contemporánea, núm. 91 (2), 2016 y el libro Memoria, Imagen e Historia. La

Segunda República en el cine de ficción (imprenta). Ha intervenido como conferenciante, ponente y coordinador de mesas en congresos y jornadas tanto en España como en Reino Unido, Irlanda y Portugal.

email— $\underline{\text { ibm@ @ezeroak.euskaltel.es }}$ 
FILMHISTORIA Online Vol. 29, núms. 1-2 (2019) · ISSN: 2014-668X 